\title{
ERRATUM
}

\section{Erratum to: Morphological, Physisological and Antioxidant Responses of some Iranian Grapevine Cultivars to Methyl Jasmonate Application}

Siamak Shirani Bidabadi*, Hamidreza Ghobadi, Bahram Baninasab, Marzieh Afazel

Erratum to: J. Crop Sci. Biotech. 16(4): 277-283

DOI No. 10.1007/s12892-013-0096-4

1. In page 277 , the authors' fax number is:

“+98-311-3913447”

2. The running title is:

"Responses of Grapevine to Methyl Jasmonate Application"

3. In page 279, the time for one cited article "Velikova et al. (2005)" was incorrect. The correct time should be as follows:

"Velikova et al. (2000)"

4. In references section page $282 \& 283$, two references should be added as follows:

"Mohammad Babar A, Singh N, Shohael A, Eun J, Paek K. 2006. Phenolics metabolism and lignin synthesis in root suspension cultures of Panax ginseng in response to copper stress. Plant Sci. 171: 147-154"

$\&$

"Premachandra GS, Saneoka H, Ogata S. 1991. Cell membrane stability and leaf water relations as affected by potassium nutrition of water-stressed maize. J. Exp. Bot. 42: 739-745"

5. In page 283 , one reference should be deleted which is:

"Velikova V, Loreto F. 2005. On the relationship between isoprene emission and thermo tolerance in Phragnites ausrralis leaves exposed to high temperatures and during the recovery from a heat stress. Plant, Cell Environ. 28: 318-327"

We apologize to readers for the mistakes.

The online version of the original article can be found at http://link.springer.com/article/10.1007\%2Fs12892-013-0096-4.

Siamak Shirani Bidabadi

Hamidreza Ghobadi

Bahram Baninasab

Marzieh Afazel

Department of Horticulture, College of Agriculture, Isfahan University of Technology, IUT Isfahan, 84156-83111, Iran 